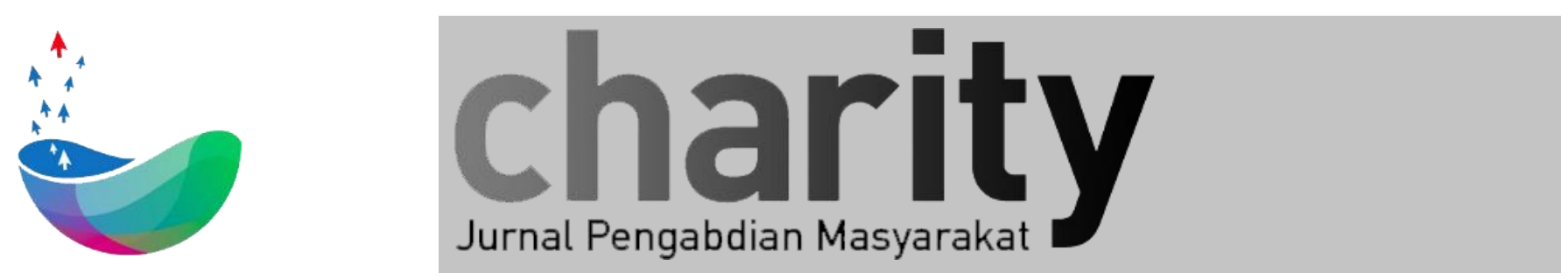

\title{
Implementasi E-Learning Untuk Meningkatkan Kualitas Pembelajaran IPA Pada Siswa Madrasah Tsanawiyah Ar- Ruhama
}

\author{
Ari Yanuar Ridwan ${ }^{1}$, M. Fahrul Rizal ${ }^{2}$, M. Deni Akbar ${ }^{3}$, Yahdi Siradj ${ }^{4}$, Agus Kusnayat ${ }^{5}$ \\ ${ }^{1}$ Program Studi S1 Teknik Industri, Fakultas Rekayasa Industri, Universitas Telkom \\ ${ }^{2}$ Program Studi D4 Multimedia, Fakultas Ilmu Terapan, Universitas Telkom \\ Program Studi S1 Teknik Industri, Fakultas Rekayasa Industri, Universitas Telkom \\ Program Studi D4 Multimedia, Fakultas Ilmu Terapan, Universitas Telkom \\ Program Studi S1 Teknik Industri, Fakultas Rekayasa Industri, Universitas Telkom \\ * ariyanaur@telkomuniversity.ac.id, denimath@telkomuniversity.ac.id
}

\section{INFO ARTIKEL}

Diterima 07 Februari 2020

Direvisi 26 Agustus 2020

Disetujui 27 Agustus 2020

Tersedia Online 28 Agustus 2020

Keyword: e-Learning, Mata Pelajaran IPA,

\begin{abstract}
ABSTRAK
Tujuan pengabdian masyarakat dengan skema kolaborasi internal ini adalah untuk menghasilkan e-learning yang disesuaikan dengan kebutuhan sekolah di tingkat Madrasah Tsanawiyah khususnya untuk mata pelajaran IPA di Madrasah Tsnawiyah (MTs) Ar-Ruhama Kuningan Jawa Barat. Kendala yang dihadapi saat ini adalah proses pembelajaran yang masih konvensional sehingga ada kendala keterbatasan waktu pengajaran dan ruang untuk melaksanakan praktikum. Sehingga diperlukan suatu sistem e-learning yang bisa membantu proses pembelajaran khususnya pembelajaran IPA. Tahapan aktivitas dibagi ke dalam tiga tim yang terdiri dari: (1) Tim 1: Mengembangkan sistem e-learning; (2) Tim 2: Pelatihan penggunakan e-learning dan pengembangan konten pembejaran; (3) Tim 3: Implementasi konten pembelajaran IPA berbasis e-Learning. Output yang diharapkan dari pengabidian kepada masyarakat ini adalah: (1) Adanya GuruGuru yang bisa mengembangkan konten pembelajaran berbasis e-Learning; (2) Adanya konten pembelajaran IPA berbasis e-learning; (3) Adanya sistem elearning. Sehingga pada akhirnya ada outcome yaitu: (1) Peningkaatan nilai ratarata mata pelajaran IPA; (2) Peningkatan nilai rata-rata Ujian Nasional Mata Pelajaran IPA; (3) Peningkatan prestasi juara olimpiade sain tingkat provinsi dan nasional. Evaluasi Pelaksanaan dilakukan dengan cara: (1) Penyebaran kuisioner untuk mengukur pencapaian output/outcome dari hasil implementasi e-learning; (2) kunjungan dan observasi lapangan.
\end{abstract}




\section{Pendahuluan}

Madrasah Tsnawiyah Ar-Ruhama adalah Lembaga Pendidikan yang diselenggarakan oleh Yayasan Islam Ar-Ruhama dan dinaungi Kementrian Agama Kabupaten Kuningan Jawa Barat yang berdiri sejak tahun 2005. MTs Ar Ruhama memiliki Visi: Terwujudnya Santriwan santriwati yang sholih, pintar, terampil dan peduli, yang diridhoi Allah SWT. Dan dibanggakan orangtua dan umat dalam rangka mewujudkan do'a Robbana Atina Fiddunya Hasanah Wa Fil Akhiroti Hasanah Wa Qinaa 'Adzaabannar.

Sejak awal berdiri Yayasan Islam Ar-Ruhama telah berkonsentrasi di bidang pendidikan Islam dengan menyelenggarakan pendidikan tingkat Madrasah Ibtidaiyah dan Madrasah Tsanawiyah. Hal ini dilakukan dalam rangka mencerdaskan bangsa dan turut serta mensukseskan dunia pendidikan di Negeri Indonesia yang tercinta ini khususnya di Kabupaten Kuningan Jawa Barat.

Penguasaan dan penggunaan teknologi khususnya bidang Teknologi Informasi dan Komunikasi (TIK) adalah kewajiban bagi guru-guru dalam meningkatkan kualitas pembelajaran [3]. guru adalah sebagai pengelola kegiatan proses belajar mengajar dimana dalam hal ini guru bertugas untuk mengarahkan kegiatan belajar siswa agar bisa mencapai tujuan pembelajaran [1].

Analisis permasalah yang dihadapi oleh Madrasah Tsnawiyah Ar-Ruhama ditampilkan dalam bentuk tabel weakness (kelemahan internal) dan threats (ancaman ekseternal) pada tabel 1.

Tabel 1. weakness (kelemahan internal) dan threats (ancaman ekseternal) Madrasah Tsnawiyah Ar-Ruhama

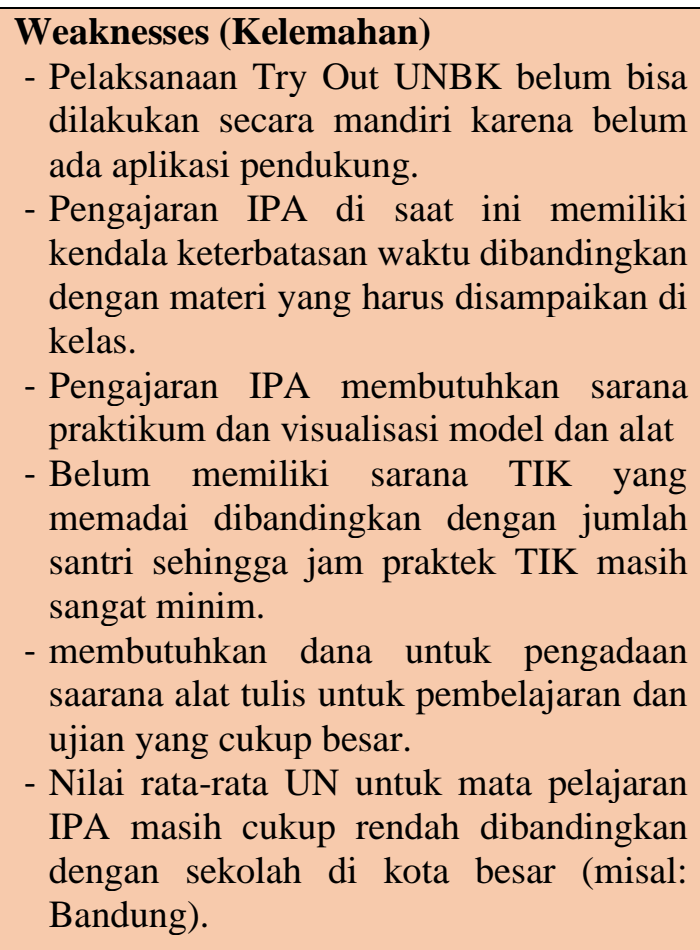

- Pelaksanaan Try Out UNBK belum bisa dilakukan secara mandiri karena belum ada aplikasi pendukung.

- Pengajaran IPA di saat ini memiliki kendala keterbatasan waktu dibandingkan dengan materi yang harus disampaikan di kelas.

- Pengajaran IPA membutuhkan sarana praktikum dan visualisasi model dan alat

- Belum memiliki sarana TIK yang memadai dibandingkan dengan jumlah santri sehingga jam praktek TIK masih sangat minim.

- membutuhkan dana untuk pengadaan saarana alat tulis untuk pembelajaran dan ujian yang cukup besar.

- Nilai rata-rata UN untuk mata pelajaran IPA masih cukup rendah dibandingkan dengan sekolah di kota besar (misal: Bandung).

\section{Threats (Ancaman)}

- Pengajaran sedang bertransformasi menjadi pengajaran berbasis digital tanpa meninggalkan sepenuhnya juga model konvensional

- Dampak negative akibat teknologi digital, social media, dan gadget

- Masuknya Lembaga Pendidikan dari luar negeri yang bisa membawa budaya yang tidak sesuai dengan budaya Indonesia dengan menawarkan Pendidikan berbasis digital. 
Tabel 2. strength (kekuatan) dan opportunities (peluang) yang dimiliki Madrasah Tsnawiyah Ar-Ruhama

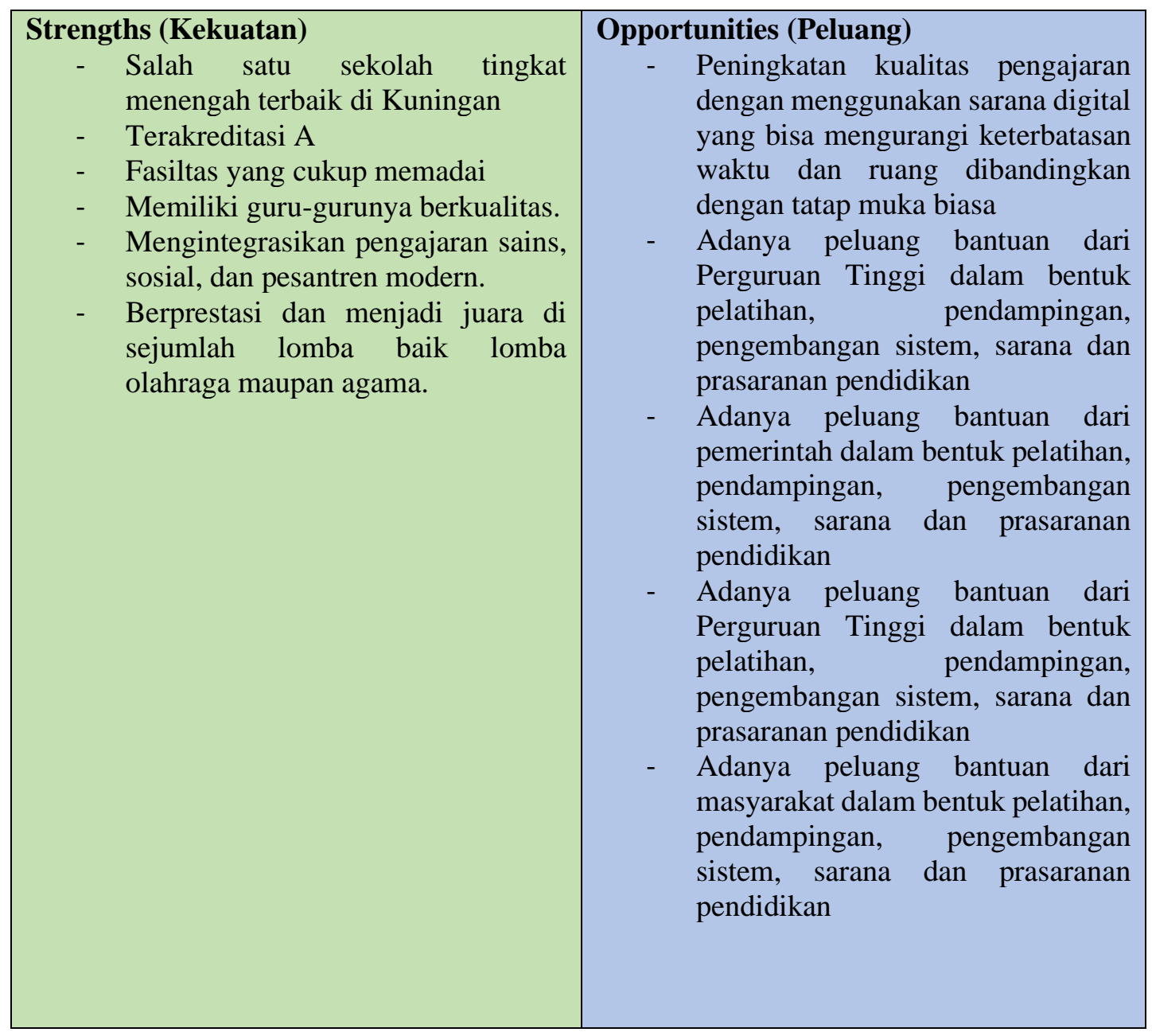

\section{Solusi Pengabdian Yang Ditawarkan}

Formulasi strategis disusun menggunakan hasil analisis SWOT pada Bab I diatas dengan menggabungkan berbagai indikator yang terdapat dalam kekuatan, kelemahan, peluang dan ancaman. Model solusi pengabdian yang ditawarkan menggunakan TOWS matriks. Namun tidak semua rencana strategi yang disusun dari TOWS matriks ini digunakan seluruhnya. Strategi yang dipilih adalah yang dapat memecahkan isu strategis masyarakat sasar.

Solusi yang ditawarkan adalah menggabungkan S-O Strategi (strategi yang disusun dengan cara menggunakan semua kekuatan untuk merebut peluang) dan W-O Strategi (strategi yang disusun dengan cara meminimalkan kelemahan untuk memanfaatkan peluang yang ada) yaitu sebagai berikut: 


\begin{tabular}{|c|c|}
\hline S-O Strategi & W-O Strategi \\
\hline Peningkatan kualitas pembelajaran IPA & $\begin{array}{l}\text { Pengembangan system pembelajaran e- } \\
\text { learning }\end{array}$ \\
\hline
\end{tabular}

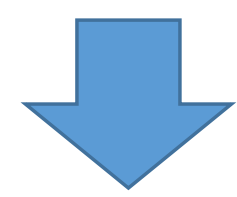

Solusi pengabdian yang ditawarkan:

Implementasi E-Learning Untuk Meningkatkan Kualitas Pembelajaran IPA di MTs Ar-Ruhama Kuningan

E-learning sangat bermanfaat dalam penyampaian bahan belajar, selain itu e-learning bisa membantu guru dalam proses belajar mengajar dan juga bisa membantu guru dalam melaksanakan aktifitas pemberian latihan soal peraktek kepada siswa dengan mengifisienkan waktu karena sistem e-learning dilengkapi dengan waktu yang ditentukan dalam proses mengerjakan soal sehingga mengasah kemampuan siswa untuk berfikir dalam mengerjakan soal latihan [2] [4].

\section{Metode Pelaksanaan Kegiatan}

Bentuk kegiatan dari Program Pengabdian Masyarakat ini akan dilakukan secara bertahap, sesuai dengan target pekerjaan dari masing-masing Tim PkM.

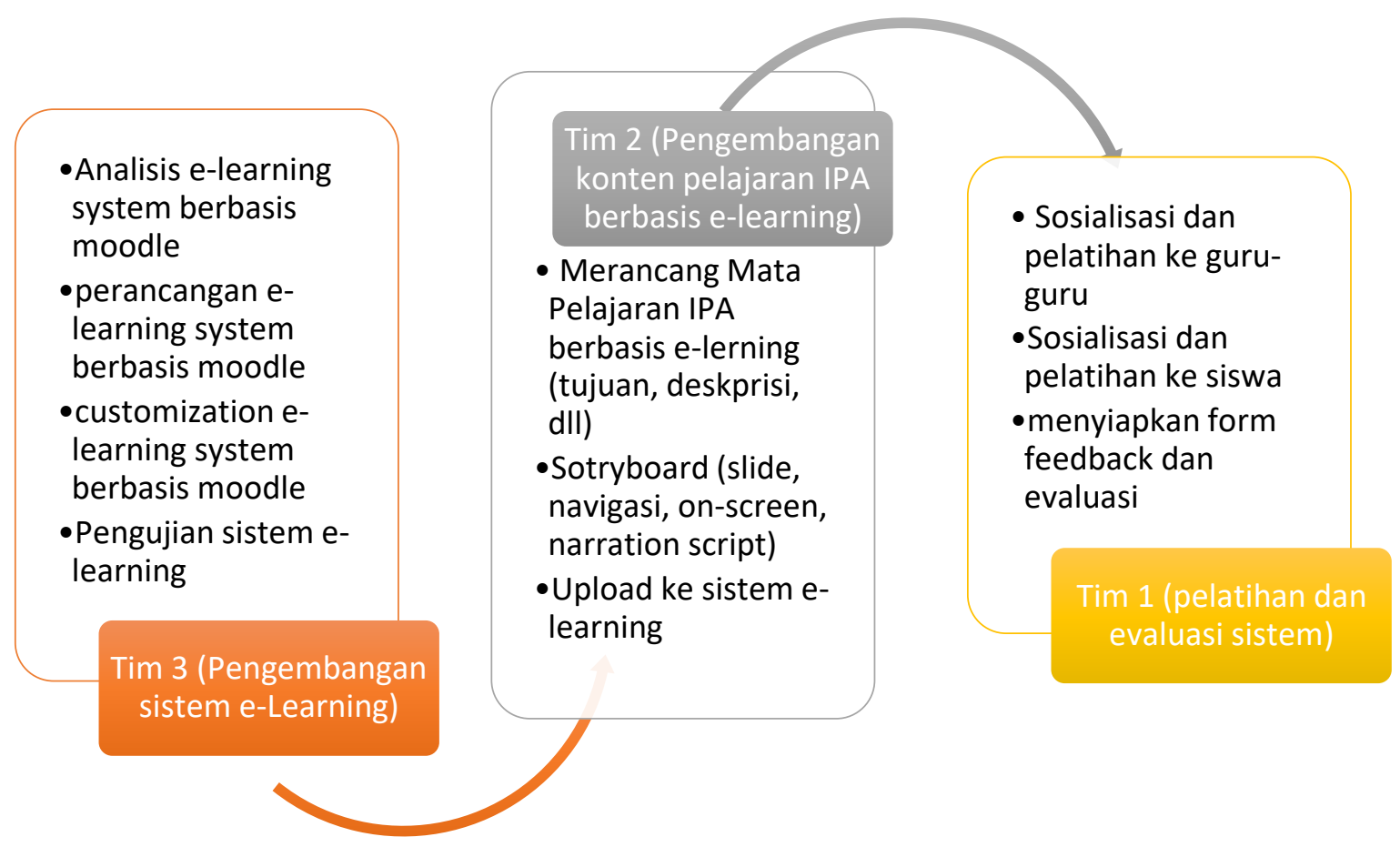

Gambar 1. Tahapan Kegiatan PkM Kolaborasi yang direncanakan 
Pembagian Tugas dan Kegiatan setiap TIM, adalah sebagai berikut:

\section{Tim 3 (Pengembangan sistem e-Learning)}

- Analisis e-learning system berbasis moodle

- perancangan e-learning system berbasis moodle

- customization e-learning system berbasis moodle

- Pengujian sistem e-learning

2. Tim 2 (Pengembangan konten pelajaran IPA berbasis e-learning)

- Merancang Mata Pelajaran IPA berbasis e-lerning (tujuan, deskprisi, dll)

- Sotryboard (slide, navigasi, on-screen, narration script)

- Upload ke sistem e-learning

3. Tim 1 (pelatihan dan evaluasi sistem)

- Sosialisasi dan pelatihan ke guru-guru

- Sosialisasi dan pelatihan ke siswa

- menyiapkan form feedback dan evaluasi

\section{Partisipasi Mitra Dalam Pelaksanaan Program}

kegiatan PkM ini akan bekerja secara bertahap terdasarkan pembagian tugas dalam tiga tim di atas. MTs Ar-Ruhama sebagai mitra, dilibatkan dalam setiap tahapan kegiatan untuk bisa mendapatkan hasil sesuai yang dibutuhkan oleh mitra.

Berikut ini partisipasi yang dilakukan oleh pihak mitra MTs Ar-Ruhama sesuai dengan aktivitas yang dilakukan oleh setiap tim:

\section{Tim 3 (Pengembangan sistem e-Learning)}

- Mitra membantu untuk menyiapkan data untuk kepentingan analisis elearning system berbasis moodle

- Mitra membantu untuk menyiapkan SOP untuk kepentingan perancangan elearning system berbasis moodle

- Mitra membantu untuk kepentingan pengujian sistem e-learning

2. Tim 2 (Pengembangan konten pelajaran IPA berbasis e-learning)

- Mitra membantu untuk merancang Mata Pelajaran IPA berbasis e-lerning (tujuan, deskprisi, dll)

- Mitra membantu untuk membuat sotryboard (slide, navigasi, on-screen, narration script)

- Mitra membantu untuk melakukan upload ke sistem e-learning

3. Tim 1 (pelatihan dan evaluasi sistem)

- Mitra membantu untuk dalam rangka sosialisasi dan pelatihan ke guru-guru

- Mitra membantu untuk dalam rangka sosialisasi dan pelatihan ke siswa

- Mitra membantu untuk mengisi form feedback dan evaluasi

\section{Keberlanjutan Program}

Sistem e-learning ini selanjutnya akan digunakan dan dikembangkan di lingkungan MTs ArRuhama dalam menunjang proses pembelajaran bukan hanya untuk mata pelajaran IPA namun juga untuk mata pelajaran lain misalnya mata pelajaran diniyah. Tim dari Universitas Telkom akan terus memonitor dan melakukan evaluasi implementasi sistem e-learning ini karena sesuai dengan roadmap pengabdian pada tahap selanjutnya akan coba untuk diimplementasikan melibatkan lebih dari satu sekolah sehingga terjadi suatu kolaborasi. Dimana konten Learning Management System (LMS) Berbasis Moodle ini kemudian dikembangkan menjadi untuk mata pelajaran lain. 


\section{Evaluasi Kuisioner Hasil Pelaksanaan Kegiatan}

Berdasarkan kuesioner yang dibarkan kepada guru peserta pengabdian masyarakat diperoleh bahwa:

1. $57,8 \%$ peserta sangat setuju bahwa Program pengabdian masyarakat ini sudah sesuai dengan tujuan kegiatan itu sendiri, dan 42,2\% menyatakan setuju

2. $63,2 \%$ peserta sangat setuju bahwa Program pengabdian masyarakat ini sudah sesuai dengan kebutuhan masyarakat sasarnya, dan 36,8\% menyatakan setuju

3. $36,8 \%$ sangat setuju bahwa Waktu pelaksanaan program pengabdian masyarakat ini relatif telah mencukupi sesuai kebutuhan, 47,4 \% menyatakan setuju, 10,5\% menyatakan tidak setuju, dan 5,3\% menyatakan sangat tidak setuju.

4. $78,9 \%$ peserta sangat setuju bahwa Dosen dan mahasiswa Universitas telkom bersikap ramah, cepat dan tanggap membantu selama kegiatan, dan $21,1 \%$ menyatakan setuju

5. $94,7 \%$ peserta sangat setuju bahwa Masyarakat setempat menerima dan mengharapkan program pengabdian masyarakat Universitas Telkom saat ini dan masa yang akan datang, dan 5,3\% menyatakan setuju

Secara keseluruhan, berdasarkan 5 aspek yang dievaluasi melalui peserta pengabdian masyarakat dapat disimpulkan bahwa kegiatan pengabdian masyarakat yang dilakukan sesuai dengan tujuan diadakanya kegiatan pengabdian masyarakat, sangat diterima, bermanfaat, membantu guru di lingkungan Madrasah Tsanawiyah pondok pesantren ArRuhama, dan guru di pondok pesantren ini mengharapkan program pengabdian masyarakat Universitas Telkom saai ini akan diadakan lagi di masa yang akan datang.

\section{Photo-Photo Kegiatan}
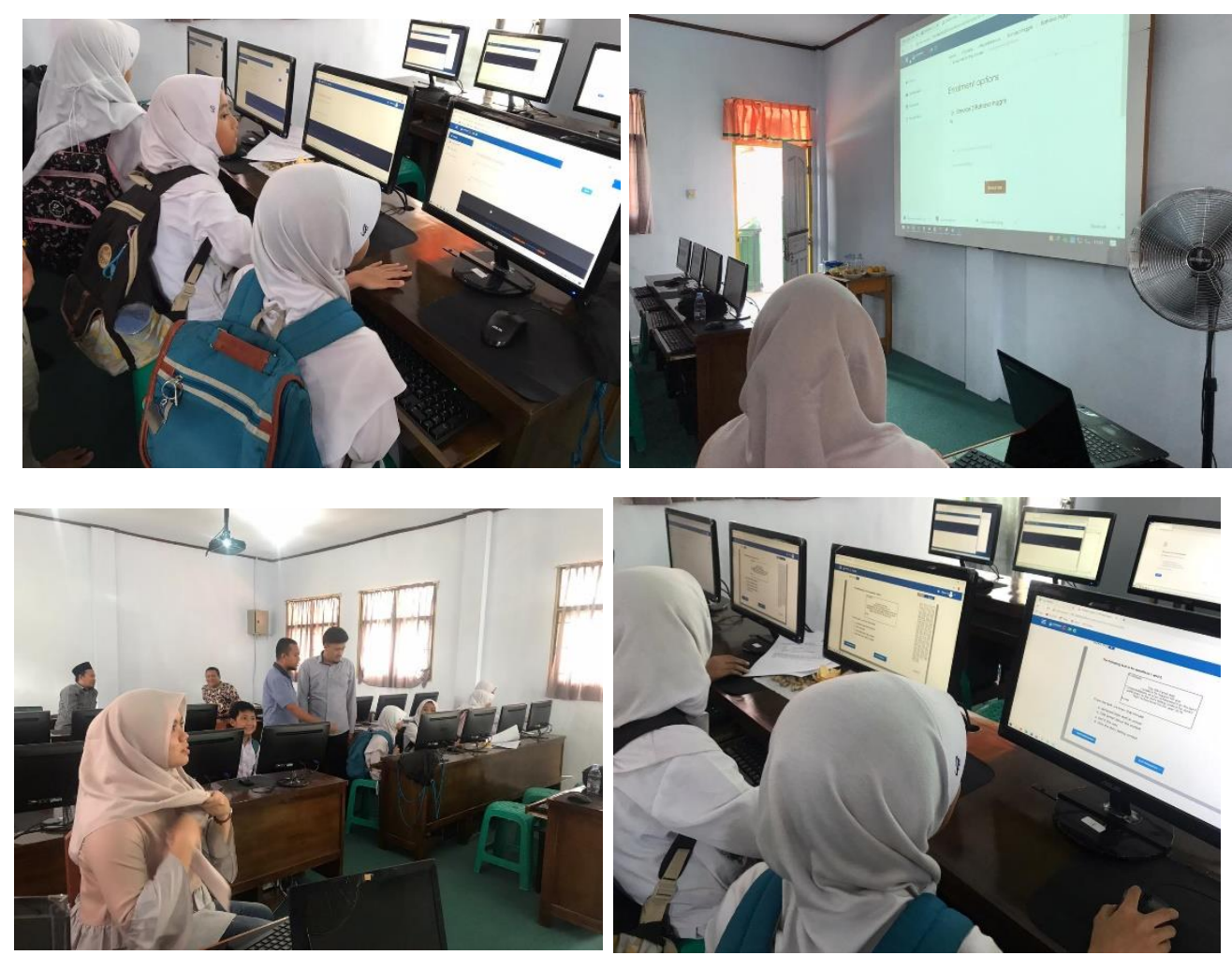

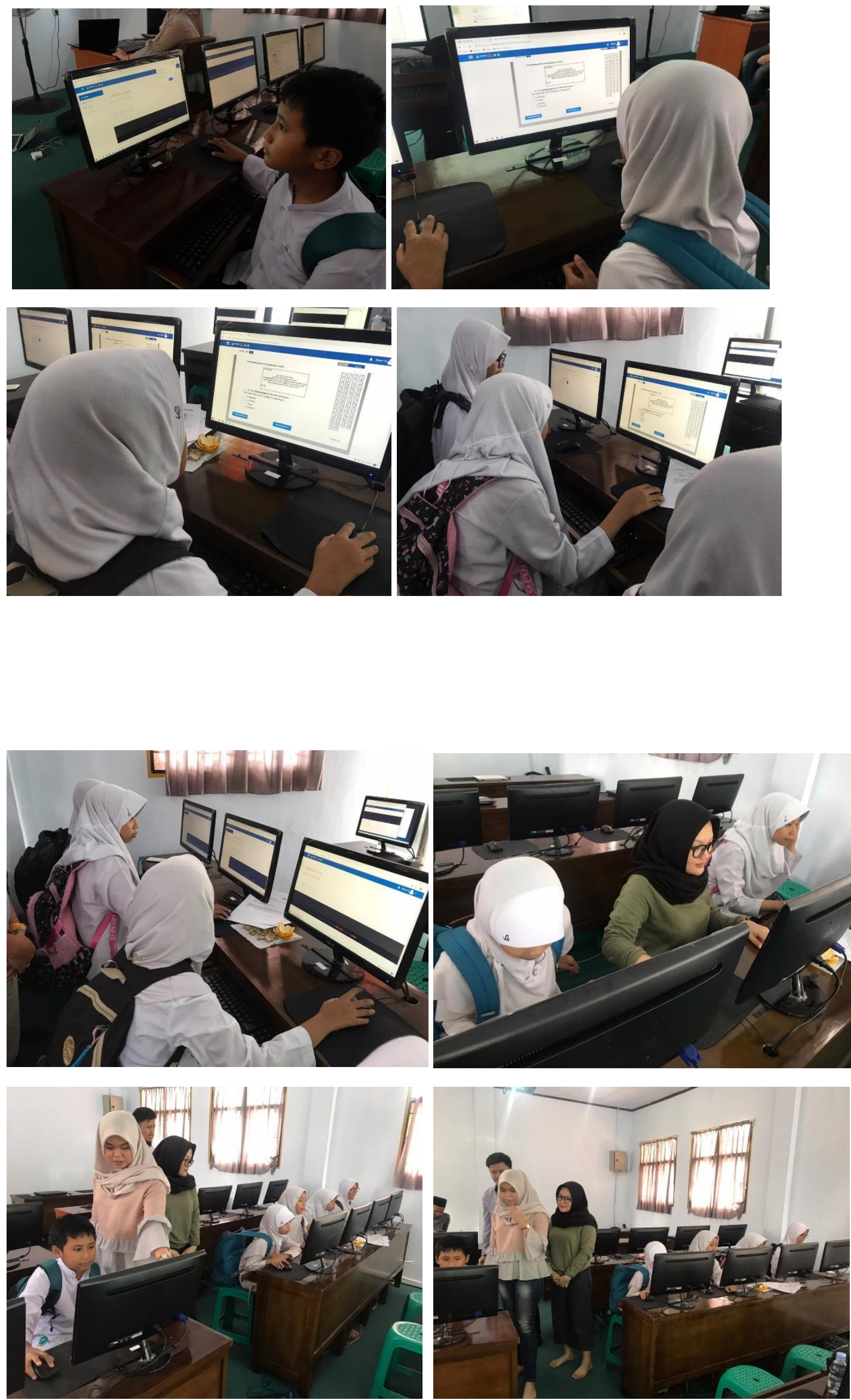

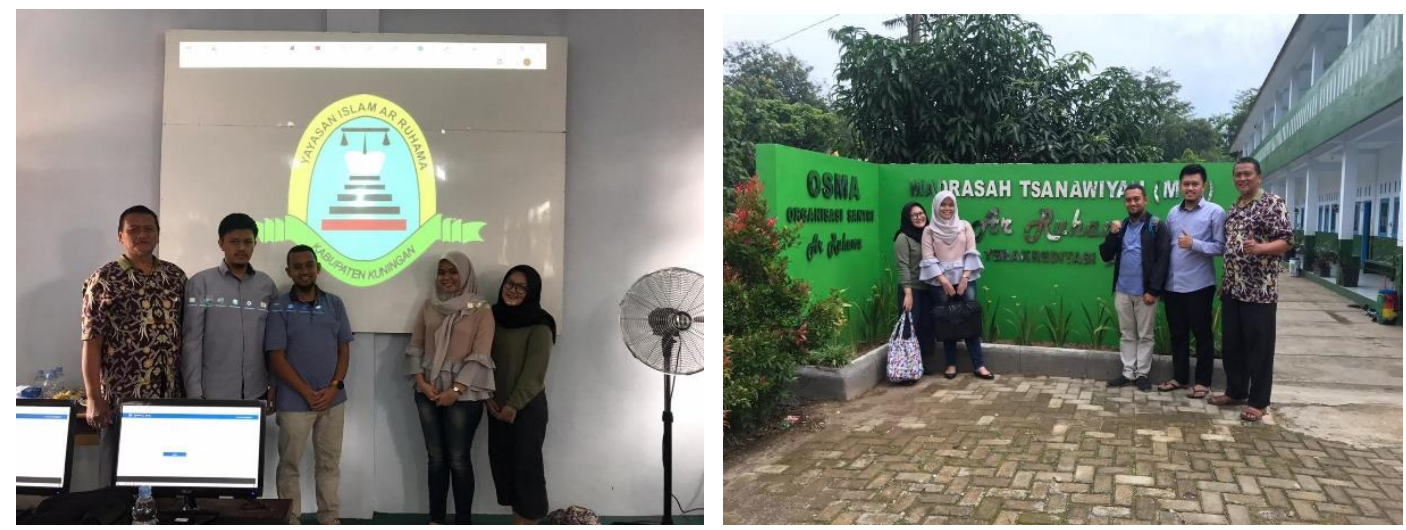

Gambar 2. Kegiatan Pengabdian Masyarakat

\section{DAFTAR PUSTAKA}

[1] Muthmainnah, Fajriana, Deassy Siska. Pemanfaatan Teknologi Informasi Untuk Meningkatkan Kualitas Pembelajaran. Techsi Vol. 9, No. 2, Oktober 2017

[2] Nirsal, Syafriadi. E-Learning Pada Sekolah Menengah Pertama Pesantren Modern Datok Sulaiman Palopo. Seminar Nasional Teknologi Informasi dan Komputer FTKOM UNCP, Oktober 2017

[3] Waaly, A.N., Ridwan, A.Y., Akbar, M.D. Development of sustainable procurement monitoring system performance based on Supply Chain Reference Operation (SCOR) and Analytical Hierarchy Process (AHP) on leather tanning industry. International Mechanical and Industrial Engineering Conference (IMIEC) 2018, MATEC Web of Conferences

[4] Hansi Effendi, Nurindah Dwiyani. Learning Management System Sebagai Alternatif Pembelajaran Untuk Meningkatkan Kualitas Belajar Di Sekolah Menengah Pertama Di Payakumbuh, Kabupaten Lima Puluh Kota. UNES Journal of Community Service Volume 3, Issue 2, December 2018

[5] Ridwan, A.Y., Mubassiran, M., \& Syafiq, S. (2015). Pengembangan Prototype Sistem Monitoring Logistik Beras (Studi Kasus di Badan Ketahanan Pangan Provinsi Jawa Barat). Jurnal Rekayasa Sistem \& Industri (JRSI), 2(02), 28-34 